\title{
Credit Constraints and Household Selection of Financial Assets
}

\author{
Guofei Wang \\ School of Economics, Jinan University, Guangzhou, China \\ Email:542435295@qq.com
}

Received 12 January 2016; accepted 19 February 2016; published 22 February 2016

Copyright (C) 2016 by authors and Scientific Research Publishing Inc.

This work is licensed under the Creative Commons Attribution International License (CC BY). http://creativecommons.org/licenses/by/4.0/

(c) (i) Open Access

\begin{abstract}
Based on the micro-data of China Household Finance Survey, this paper analyzes the effects of credit constraints on household selection of financial assets empirically. The results show that credit constraints have the significant negative impact on participation rate and allocation ratio of savings, stock, risky financial assets. Credit constraints keep families from holding much savings. Those families who face credit constraints have to use their own money to meet the demand of funds without bank loans. Those families who face credit constraints are no willing to invest in stock market and hold less risky assets because of their lower risk tolerance. Besides, credit constraints can increase the participation rate of informal borrowing and reduce household private lending. There are few domestic articles analyzing the relationship between credit constraints and household selection of financial assets. Therefore, this paper can be more of reference value for the follow-up study. Meanwhile, the results show that reducing credit constraints is helpful for the household participation in capital market.
\end{abstract}

\section{Keywords}

Credit Constraints, Financial Assets, Stock Market Participation, Household Finance

\section{Introduction}

In recent years, the economy of China developed stably, domestic residents' disposable income increased rapidly as well. National Bureau of Statistics announced that the growth rate of per capita disposable income in China had reached $8 \%$ in 2014, which was faster than the economic growth rate. Because of the rapidly increasing of domestic residents' disposable income, the scale of household financial assets becomes larger and larger. The selection of financial assets has become the core issue of household financial investment. At the same time, the scale of household debt also increased rapidly, from 17.2 billion in 1997 to 5.54 trillion in 2009, which had 
achieved a 322-fold increase. In the past ten years, mortgages, consumer loans and credit card loans had greatly changed the habits of domestic residents' consumption and saving. Many families prefer to use the credit instruments to smooth the demand of consumption and investment, rather than only rely on savings to adjust the income and expenditure. Therefore, we have every reason to believe that the behavior of household borrowing will greatly affect household economic decision.

\section{Literature Review}

Western scholars have been studying household portfolio choice since the early consumption theory was put forward. In the consumption theory, life cycle theory and permanent income hypothesis both indicate that based on the situation of current income and the expectations of future income, families will choose different asset allocations to smooth consumption in different stages. With the internal conditions unchanged, household expectation of income is largely affected by the external credit conditions. Whether a family can borrow enough money from financial institution without limits decides whether the household asset allocation is effective or not. Therefore, credit constraints can affect the selection of financial assets through affecting the expectation of future income. Early credit constraints theory was proposed by Flavin (1981), and his research indicated that because of credit constraints, consumption will be oversensitive to income [1]. Zeldes (1989) used the data of Panel Study of Income Dynamics (PSID) to do the time series analysis and cross-sectional analysis, he found that credit constraints can significantly affect the expectation of future income so that household consumption and savings can be affected by credit constraints largely [2]. Haliassos, M. and Michaelides, A. (2003) established an infinite life-cycle model under credit constraints, and studied the household portfolio specialization puzzle for impatient consumers with access to risky and riskless assets [3]. Guiso et al. (2000) compared portfolio behavior across countries and contrasted theoretical predictions to empirical findings, they concluded that because of credit constraint, young household would like to invest real assets rather than financial assets, but elder household is opposite [4]. In theory, western scholars used to establish consumption-savings model to analyze household portfolio choice (Stiglitz, 1981; Cocco, 2005). However, western scholars focus on household heterogeneity such as age, education, health, housing and income etc. when analyzing household selection of financial assets empirically (Poterba, 1997; Heaton, 2000; Michael, 2006; Angerer, 2009).

Domestic scholars analyzed the selection of financial assets by households mainly from two aspects of macroeconomic and microeconomic. In earlier studies, domestic scholars used macroeconomic data to analyze household choice of financial assets. Yu Changqiu (2001) found that steady growth and structural changes of financial assets contributed to the development of economy [5]. He Xingqiang et al. (2009) analyzed the effect of background risk on household selection of risky assets, the result showed that higher risk of career income would lead to the lower ratio of risky assets such as stock or financial products [6]. As further research continues, household micro database has been established gradually. Therefore, some scholars started to analyze the effect of household heterogeneity such as wealth, housing, education, health, risk attitude etc. Yu Rong (2006) used questionnaire data from 10 major cities to prove that age, income, real estate, education, risk attitude and social interaction have a significant positive impact on families' participation in stock market. Also, there was a significant positive relationship between expectations of future income and proportion of shareholding [7]. Wu Weixing et al. (2011) found that although investors' health status did not significantly affect his decisions about participating in the stock and risky asset markets, it did affect how much his family invested in stocks or risky assets [8]. Wang Cong and Tian Cunzhi (2012) pointed out that risk attitude, social reaction and house holding had a significant impact on stock market participation. Meanwhile, they believed that there was a significant negative relationship between credit constraints and stock market participation [9].

According to the literature review above at home and abroad, we can learn that foreign scholars have had systematic researches on credit constraints and household selection of financial assets. However, domestic research on household finance is still at the beginning stages and there is lack of national household financial micro-data, so that domestic scholars' study on the household selection of financial assets is not enough. Also, very few domestic researches study the relationship between credit constraints and household selection of financial assets. Therefore, this paper can fill the blank of domestic researches. This paper analyzes the effects of credit constraints on household selection of financial assets by using micro-data from China Household Finance Survey. China Household Finance Survey provides systematic micro-data of household finance in China. This paper will be of more reference value for the follow-up studies of credit constraints and household finance, and 
also be of practical significance to household financial management and capital market regulator.

\section{Theoretical Hypothesis}

\subsection{Credit Constraints and Precautionary Savings}

Those families who face credit constraints cannot smooth income and expenditure by external borrowing, so their expectation of future income has greater uncertainty. Therefore, those families who face credit constraints will pay more attention to the current asset allocation and increase their precautionary savings. Leland firstly proposed the precautionary savings hypothesis which stated that the uncertainty of income will lead to the increase savings. Leland pointed out that credit constraints will lead to the greater uncertainty of future income, so those families who face credit constraints would rather holding more precautionary savings. Similarly, Haliassos and Bertaut (1995) found that credit constraints will reduce the holdings of risky assets but increase precautionary savings [10]. Guiso et al. (2000) studied the Italian household asset data, and found that credit constraint affected the holdings of risky assets through affecting the transaction cost [4]. As a result, precautionary savings would be the reasonable option for those families who face credit constraints. Above all, a hypothesis can be draw as following:

H1: Credit constraints have a positive correlation with household savings.

\subsection{Credit Constraints and Risk Tolerance}

Whether a family can obtain credit support from the formal credit channels like banks depends on repayment capacity. Repayment capacity mainly includes sustainable Income, credit status and mortgage assets. Jappelli (1990) pointed out that compared with the families without credit constraints, those families who face credit constraints own fewer assets and less income [11]. When families have insufficient assets and income, their risk tolerance becomes lower. Those families with lower risk tolerance would rather to choose low-risk financial assets instead of high-risk financial assets such as stock. Credit conditions can reflect different risk tolerance between different families. Rational economic behaviors can be affected by risk tolerance, so families with lower risk tolerance will probably choose low-risk financial assets. Low-risk financial assets mainly include savings, and high-risk financial assets mainly include stock, funds, derivatives etc. Above all, two hypotheses can be draw as following:

H2: Credit constraints have a negative correlation with stock holding and risky financial assets.

\subsection{Credit Constraints and Private Borrowing and Lending}

China Household Finance Survey (CHFS) states that the level of formal credit availability, which means the degree of meeting the credit demand, is $51.6 \%$, while the level of private borrowing availability is $44.4 \%$. CHFS report shows that meeting household credit demand mainly relies on formal credit channels like banks, but private borrowing also plays an indispensable role in reducing the pressure of credit demand. Compared with private borrowing, formal credit channels have relatively tough approval conditions and high transaction costs. Those families who are unable to get loans from banks have to borrow money from friends and relatives. In reality, small shortage of funds in production, operation, daily consumption and education spending etc. will be more likely to be met by private borrowing. Therefore, those families who face credit constraints will tend to use private borrowing to solve the problem of shortage of funds. Meanwhile, those families who face credit constraints will reduce private lending because they lack of money. Above all, two hypotheses can be draw as following:

H3a: Credit constraints have a positive correlation with private borrowing.

H3b: Credit constraints have a positive correlation with private lending.

\section{Data, Model and Variables}

\subsection{The Selection of Sample Data}

In this paper, the source of sample data is 2011 China Household Finance Survey (CHFS). CHFS has investigated 320 communities in 80 counties of 25 provinces, and collected household finance micro-data of 8438 families. The survey consists of four parts, including demographics, assets and liabilities, insurance and social secu- 
rity, expenditure and income.

\subsection{Model Specification}

This paper firstly analyzes the effect of credit constraints on household participation in financial assets. Since the explained variable is a dummy variable, Probit model should be used as the empirical model. The model specification is as follows:

$$
\text { Probit }\left(\text { Financial participantion }_{i}=1\right)=\alpha \text { Constraint }_{i}+\beta X_{i}+\varepsilon_{i}
$$

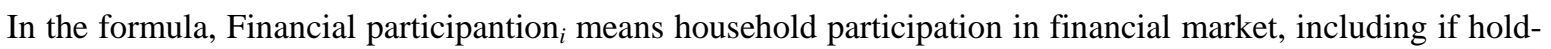
ing savings, if investing stock, if investing risky financial assets and if having private borrowing. Constraint ${ }_{i}$ means whether a family faces credit constraints or not. $X_{i}$ mean controlled variables, $\varepsilon \sim N\left(0, \sigma^{2}\right)$.

Furthermore, this paper will analyze the relationship between credit constraints and the proportion of each financial asset in household allocation. Because the proportion of financial asset is between 0 and 1, least square method is not a suitable empirical model. Therefore, Tobit model will be used in this paper, and the model specification is as follows:

$$
\begin{gathered}
\text { Financial assets proportion }_{i}=\delta \text { Constraint }_{i}+\theta X_{i}+\varepsilon_{i} \\
\text { Financial assets proportion }_{i}=\max \left(0 \text {, Financial assets proportion }{ }_{i}\right)
\end{gathered}
$$

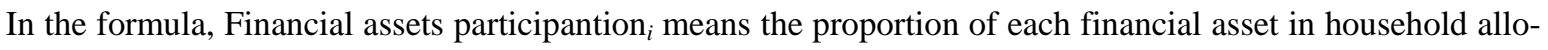
cation, including the proportion of saving, the proportion of stock, the proportion of risky financial assets and the proportion of private lending to the total financial assets.

\subsection{Variable Description}

\subsubsection{Explained Variable}

In Probit model, the explained variables are dummy variables including if a family holding savings, if investing stock, if investing risky financial assets and if having private borrowing. In Tobit model, the explained variables include the proportion of saving, the proportion of stock, the proportion of risky financial assets and the proportion of private lending in the total financial assets. Savings means the sum of demand deposits and time deposits. Risky financial assets refer to the sum of stock, bonds, fund, derivatives, financial products, non-RMB assets, gold and private lending.

\subsubsection{Explanatory Variable}

In this paper, the main explanatory variable is credit constraints. Conceptually, credit constraints describe the situation that people who need money cannot obtain credit funds from formal financial market. In earlier studies, credit constraints could not be observed or measure directly. Therefore, many scholars only could indirectly measure credit constraints by observing consumer sensitivity to changes in income or estimating the differences between actual consumption and expected consumption. However, this way of measuring credit constraints was not suitable for empirical analysis. Therefore, Jappelli (1990) proposed a more concrete and operable method. Jappelli stated that when a family's application for a loan was rejected or they didn't apply for a loan just because afraid of being rejected, this family was facing credit constraints. Jappelli (1990) used data from survey of consumer finance to measure credit constraints, his judgment standards focus on "application for a loan was rejected" or "without application for a loan because afraid of being rejected". In follow-up studies, Jappelli's method was widely used (Feder, 1990; Flavin, 2002; Grant, 2007).

Therefore, this paper will continue to use Jappelli's to identify those families who face credit constraints. In China Household Finance Survey, those families who answered they didn't have a loan from banks because application was rejected or they didn't apply because afraid of being rejected, are defined as families who face credit constraints.

\subsubsection{Controlled Variables}

Controlled variables include total household income, household real estate, family size, if being urban, gender of 
the host, age of the host, risk attitude and education level. Besides, risk attitude can be divided into risk-preference and risk-aversion. Education level can be divided into primary education, secondary education and higher education.

\subsubsection{Instrumental Variable}

In order to solve endogeneity that may exist in empirical text, this paper will use the Instrumental variable for a two-stage regression. Cheng Yu and Luo Dan (2009) used the distance between home address and nearest financial institution as the instrumental variable, in order to solve the endogenous influence of credit constraints on famers' business startups [12]. Similarly, this paper chooses the distance (measured by time needed) between home address and the centre of city as the instrumental variable. Those families who are closer to the downtown can be more easily accessible to financial institutions, so they have more opportunities to know and participate in the credit market. Also, the distance between home address and the centre of city will not directly affect household selection of financial assets. Therefore, the distance between home address and the centre of city can be a suitable instrumental variable. Meanwhile, in the subsequent robustness test, weak identification test has been passed.

\section{Empirical Analysis}

\subsection{Probit Regression Analysis}

In Table 1, the first column shows that credit constraints have a significant negative correlation with holding

\begin{tabular}{|c|c|c|c|c|}
\hline & (1) & (2) & (3) & (4) \\
\hline & Savings & Stock & Risky Assets & Private Borrowing \\
\hline \multirow[t]{2}{*}{ Credit constraints } & $-0.050^{* * *}$ & $-0.019^{* * * *}$ & $-0.034^{* * *}$ & $0.210^{* * * *}$ \\
\hline & $(-3.54)$ & $(-3.1)$ & $(-3.07)$ & (19.39) \\
\hline \multirow[t]{2}{*}{ Real estate } & $0.000^{* * *}$ & $0.000^{* * *}$ & $0.000^{* * * *}$ & $-0.000^{* * *}$ \\
\hline & $(3.41)$ & $(9.75)$ & (8.19) & $(-4.34)$ \\
\hline \multirow[t]{2}{*}{ Household income } & $0.000^{* * * *}$ & $0.000^{* * * *}$ & $0.000^{* * *}$ & $0.000^{* * * *}$ \\
\hline & (5.58) & (7.97) & $(7.82)$ & $(-7.12)$ \\
\hline \multirow[t]{2}{*}{ Risk-preference } & -0.026 & $0.048^{* * *}$ & $0.061^{* * *}$ & $0.039^{* * * *}$ \\
\hline & $(-1.37)$ & $(6.04)$ & $(4.41)$ & (2.79) \\
\hline \multirow[t]{2}{*}{ Risk-aversion } & $-0.062^{* * *}$ & $-0.023^{* * *}$ & $-0.053^{* * * *}$ & $-0.023^{* *}$ \\
\hline & $(-4.47)$ & $(-4.01)$ & $(-5.16)$ & $(-2.29)$ \\
\hline \multirow[t]{2}{*}{ Family size } & $-0.007^{*}$ & -0.002 & -0.001 & $0.028^{* * * *}$ \\
\hline & $(-1.83)$ & $(-1.01)$ & $(-0.23)$ & (10.69) \\
\hline \multirow[t]{2}{*}{ Male } & $0.022^{*}$ & $-0.016^{* * * *}$ & 0.002 & $0.014^{*}$ \\
\hline & $(1.91)$ & $(-3.49)$ & $(0.19)$ & (1.68) \\
\hline \multirow[t]{2}{*}{ Age } & -0.000 & 0.000 & $-0.002^{* * *}$ & $-0.003^{* * *}$ \\
\hline & $(-0.38)$ & (1.39) & $(-6.96)$ & $(-9.58)$ \\
\hline \multirow[t]{2}{*}{ Primary education } & $0.181^{* * *}$ & $0.048^{* * * *}$ & $0.106^{* * *}$ & $-0.037^{* * * *}$ \\
\hline & $(8.91)$ & (3.32) & (5.28) & $(-2.69)$ \\
\hline \multirow[t]{2}{*}{ Secondary education } & $0.264^{* * *}$ & $0.169^{* * *}$ & $0.193^{* * *}$ & $-0.051^{* * *}$ \\
\hline & (11.76) & $(6.8)$ & $(7.48)$ & $(-3.32)$ \\
\hline \multirow[t]{2}{*}{ Higher education } & $0.320^{* * * *}$ & $0.250^{* * * *}$ & $0.271^{* * * *}$ & $-0.089^{* * *}$ \\
\hline & (13.12) & (8.42) & $(9.42)$ & $(-5.33)$ \\
\hline \multirow[t]{2}{*}{ Urban } & $0.084^{* * * *}$ & $0.035^{* * * *}$ & $0.047^{* * * *}$ & $-0.033^{* * *}$ \\
\hline & $(7.04)$ & (6.6) & $(5.06)$ & $(-3.89)$ \\
\hline $\mathrm{N}$ & 8438 & 8438 & 8438 & 8438 \\
\hline Pseudo $\mathrm{R}^{2}$ & 0.062 & 0.238 & 0.134 & 0.125 \\
\hline
\end{tabular}

Note: Figures in brackets are the t statistics. ${ }^{* * *},{ }^{* *}$ and ${ }^{*}$ represent $1 \%, 5 \%$ and $10 \%$ significance level. Figures without brackets are marginal effects, namely $\mathrm{dF} / \mathrm{dx}$. 
savings, but this result is not consistent with previous H1. A possible reason is that those families who face credit constraints have to use all of their own savings to meet the current capital demand because they cannot borrow money from banks. Therefore, those families who face credit constraints may hold little savings or no savings. The second column shows that credit constraints have a significant negative correlation with investing stock, which is consistent with H2. It means credit constraints can reduce the household participation rate of stock market. The third column shows that credit constraints have a significant negative correlation with investing risky financial assets, which is also consistent with $\mathrm{H} 2$. The fourth column shows that credit constraints have a significant positive correlation with having private borrowing, which is consistent with H3a. Those families, who face credit constraints from banks, tend to meet the need of funds through informal credit channels.

\subsection{Tobit Regression Analysis}

In Table 2, the first column shows that credit constraints have a significant negative correlation with the propor-

\begin{tabular}{|c|c|c|c|c|}
\hline & (1) & (2) & (3) & (4) \\
\hline & Savings & Stock & Risky Assets & Private Lending \\
\hline \multirow[t]{2}{*}{ Credit constraints } & $-0.104^{* * *}$ & $-0.167^{* * *}$ & $-0.086^{* * *}$ & -0.028 \\
\hline & $(-4.85)$ & $(-2.59)$ & $(-2.55)$ & $(-0.74)$ \\
\hline \multirow[t]{2}{*}{ Real estate } & $0.000^{*}$ & $0.000^{* * * *}$ & $0.000^{* * * *}$ & -0.000 \\
\hline & (1.64) & $(9.32)$ & (8.66) & $(-0.04)$ \\
\hline \multirow[t]{2}{*}{ Household income } & $0.000^{* * *}$ & $0.000^{* * *}$ & $0.000^{* * * *}$ & $0.009^{* * * *}$ \\
\hline & (2.93) & (6.13) & $(6.32)$ & (3.24) \\
\hline \multirow[t]{2}{*}{ Risk-preference } & $-0.082^{* * *}$ & $0.311^{* * * *}$ & $0.140^{* * * *}$ & 0.023 \\
\hline & $(-3.02)$ & $(5.44)$ & $(3.80)$ & $(0.53)$ \\
\hline \multirow[t]{2}{*}{ Risk-aversion } & $-0.061^{* * *}$ & $-0.181^{* * *}$ & $-0.157^{* * *}$ & $-0.127^{* * *}$ \\
\hline & $(-3.01)$ & $(-3.56)$ & $(-5.25)$ & $(-3.69)$ \\
\hline \multirow[t]{2}{*}{ Family size } & $-0.012^{* *}$ & -0.020 & -0.002 & 0.012 \\
\hline & $(-2.13)$ & $(-1.22)$ & $(-0.18)$ & (1.19) \\
\hline \multirow[t]{2}{*}{ Male } & 0.033 & 0.002 & $-0.008^{* * *}$ & $-0.014^{* * *}$ \\
\hline & (1.92) & $(1.00)$ & $(-7.57)$ & $(-11.27)$ \\
\hline \multirow[t]{2}{*}{ Age } & $0.000^{*}$ & $-0.118^{* * *}$ & 0.010 & $0.097^{* * *}$ \\
\hline & $(0.75)$ & $(-2.78)$ & $(0.39)$ & (3.23) \\
\hline \multirow[t]{2}{*}{ Primary education } & $0.313^{* * *}$ & $0.446^{* * * *}$ & $0.295^{* * * *}$ & $0.277^{* * *}$ \\
\hline & (9.79) & (3.07) & $(4.83)$ & $(3.90)$ \\
\hline \multirow[t]{2}{*}{ Secondary education } & $0.437^{* * * *}$ & $0.925^{* * *}$ & $0.452^{* * *}$ & $0.275^{* * *}$ \\
\hline & (12.08) & $(6.20)$ & (6.94) & $(3.60)$ \\
\hline \multirow[t]{2}{*}{ Higher education } & $0.499^{* * *}$ & $1.127^{* * * *}$ & $0.592^{* * * *}$ & $0.304^{* * *}$ \\
\hline & (12.66) & (7.40) & (8.69) & (3.79) \\
\hline \multirow[t]{2}{*}{ Urban } & $0.126^{* * *}$ & $0.346^{* * *}$ & $0.152^{* * * *}$ & 0.050 \\
\hline & (7.08) & (6.61) & (5.48) & (1.60) \\
\hline \multirow[t]{2}{*}{ Sigma } & $-0.254^{* * *}$ & $0.917^{* * * *}$ & $0.782^{* * * *}$ & $0.807^{* * * *}$ \\
\hline & $(-4.42)$ & (28.67) & (46.87) & (36.18) \\
\hline $\mathrm{N}$ & 8438 & 8438 & 8438 & 8438 \\
\hline Pseudo $\mathrm{R}^{2}$ & 0.0336 & 0.206 & 0.111 & 0.060 \\
\hline
\end{tabular}

Note: Figures in brackets are the t statistics. ${ }^{* * *},{ }^{* *}$ and ${ }^{*}$ represent $1 \%, 5 \%$ and $10 \%$ significance level. Figures without brackets are marginal effects, namely $\mathrm{dF} / \mathrm{dx}$. 
tion of savings in the total financial assets. The result means credit constraints can reduce the proportion of savings, in other words, credit constraints are not the cause of high savings rate in China. However, the result is not consistent with H1. The possible reason is that those families, who cannot obtain credit support from banks, have to use their own savings to solve the current demand of funds, so those families may hold little savings. The second column shows that credit constraints have a significant negative correlation with the proportion of stock, and it is consist with H2. Therefore, credit constraints not only reduce the participation rate of household stock investment, but also have a negative impact on the depth of household stock investment. The third column shows that credit constraints have a significant negative correlation with the proportion of risky financial assets. Those families who face credit constraints tend to invest riskless financial assets. The fourth column shows that credit constraints have a negative correlation with the proportion of private lending, but the result is not significant. The robustness of above results still needs further test.

\subsection{IV-Probit Regression Analysis}

In order to solve endogenous problem, this paper chooses the distance between home address and the centre of city as the instrumental variable to do the IV-Probit regression. IV-Probit can bring more objective results. In the researches of He Anhua (2014) and Lian Yujun (2014), they used two-stage least squares regression to estimate the effectiveness of instrumental variables [13] [14]. This paper also uses 2SLS regression to discuss the effectiveness of the instrumental variable. In Table 3, F statistic in first stage regression is 38.988, which is greater than the critical value of Stock-Yogo test. The critical value of Stock-Yogo test in $10 \%$ significance level is 16.38. Therefore, weak instrument problem does not exist, which means the choice of instrumental variable in this paper is suitable. Meanwhile, this paper uses Hausman test to examine the endogenous problem between credit constraints and explained variables. In Table 3, P statistics in Hausman test is 0.000, which means the endogenous problem does exists in $1 \%$ significance level, so instrumental variable is necessary.

In IV-Probit regression, credit constraints still have a significant negative correlation with holding savings, investing stock and investing risky financial assets. It means those families who face credit constraints will avoid investing stock and risk financial assets. Besides, credit constraints still have a significant positive correlation with having private borrowing. It means those families who face credit constraints have to use private borrowing to meet the financing demand when bank loans are not accessible.

\subsection{IV-Tobit Regression Analysis}

Similarly, IV-Tobit uses 2SLS regression to solve endogenous problem that exists in Tobit model. In Table 4, F statistic in first stage regression is 31.377, which is greater than the critical value of Stock-Yogo test. The critical value of Stock-Yogo test in $10 \%$ significance level is 16.38 . Therefore, weak instrument problem does not exist, which means the choice of instrumental variable in this paper is suitable. Meanwhile, Hausman test has been also used to examine the endogenous problem. In Table 4, statistics values in Hausman test are all negative. Lian Yujun (2014) had drawn a definitive conclusion. He pointed out that when statistics values in Hausman test are negative, it means endogenous problems exist [15]. Therefore, credit constraints cause the endogenous problem, so adjustment with the instrumental variable is necessary.

In IV-Tobit regression, credit constraints still have a significant negative correlation with the proportion of saving, stock and risky financial assets. Although the significance level of the marginal effect of credit constraints on risk financial assets has declined from $1 \%$ to $5 \%$, it is believed that credit constraints have the negative impact on investing risky financial assets. Besides, the significance level of the marginal effect of credit constraints on the proportion of private lending has risen from less than $10 \%$ to $5 \%$. It means credit constraints have a significant negative correlation with the proportion of private lending. Those families who face credit constraints are not willing to or unable to lend out money.

\section{Conclusion and Suggestions}

This paper used the data from 2011 China Household Finance Survey to analyze the relationship between credit constraints and household selection of financial assets. Household selection of financial assets includes participation rate and allocation ratio, so this paper uses Probit model and Tobit model to study these two aspects. The results show that credit constraints have a significant negative correlation with the participation rate and allocation ratio of savings, stock, risky financial assets. Those families who face credit constraints may hold little savings or 
Table 3. IV-Probit regression.

\begin{tabular}{|c|c|c|c|c|}
\hline & (1) & (2) & (3) & (4) \\
\hline & Savings & Stock & Risky Assets & Private Borrowing \\
\hline \multirow[t]{2}{*}{ Credit constraints } & $-0.1901^{* * *}$ & $-0.6850^{* * *}$ & $-0.2048^{* * *}$ & $0.3217^{* * *}$ \\
\hline & $(-3.17)$ & $(-4.08)$ & $(-2.74)$ & $(4.62)$ \\
\hline \multirow[t]{2}{*}{ Real estate } & 0.000 & 0.000 & $0.000^{* * * *}$ & -0.000 \\
\hline & $(0.74)$ & $(0.62)$ & (3.78) & $(-1.63)$ \\
\hline \multirow[t]{2}{*}{ Household income } & $0.000^{* * *}$ & 0.000 & $0.000^{* * *}$ & $-0.000^{* * *}$ \\
\hline & (3.39) & $(1.36)$ & (5.17) & $(-5.47)$ \\
\hline \multirow[t]{2}{*}{ Risk-preference } & -0.056 & $0.423^{* * * *}$ & $0.235^{* * * *}$ & $0.142^{* *}$ \\
\hline & $(-1.03)$ & (3.66) & $(4.04)$ & (2.15) \\
\hline \multirow[t]{2}{*}{ Risk-aversion } & $-0.131^{* * *}$ & -0.110 & $-0.178^{* * *}$ & $-0.128^{* * *}$ \\
\hline & $(-3.23)$ & $(-1.19)$ & $(-3.86)$ & $(-2.56)$ \\
\hline \multirow[t]{2}{*}{ Family size } & 0.031 & $0.165^{* * *}$ & $0.050^{* *}$ & $0.048^{* *}$ \\
\hline & $(1.61)$ & (3.13) & $(2.05)$ & $(2.10)$ \\
\hline \multirow[t]{2}{*}{ Male } & $0.082^{* *}$ & -0.077 & 0.033 & 0.020 \\
\hline & $(2.40)$ & $(-0.99)$ & $(0.83)$ & $(0.46)$ \\
\hline \multirow[t]{2}{*}{ Age } & $-0.003^{* *}$ & $-0.007^{*}$ & $-0.013^{* * *}$ & $-0.010^{* * * *}$ \\
\hline & $(-2.00)$ & $(-1.89)$ & $(-6.55)$ & $(-5.00)$ \\
\hline \multirow[t]{2}{*}{ Primary education } & $0.349^{* * *}$ & 0.095 & $0.313^{* * *}$ & 0.001 \\
\hline & (5.06) & $(0.46)$ & (3.19) & $(0.01)$ \\
\hline \multirow[t]{2}{*}{ Secondary education } & $0.501^{* * *}$ & 0.310 & $0.439^{* * *}$ & 0.052 \\
\hline & (5.29) & (1.18) & $(3.52)$ & $(0.46)$ \\
\hline \multirow[t]{2}{*}{ Higher education } & $0.629^{* * * *}$ & 0.393 & $0.593^{* * * *}$ & -0.089 \\
\hline & (5.58) & (1.30) & $(4.16)$ & $(-0.64)$ \\
\hline \multirow[t]{2}{*}{ Urban } & $0.138^{* * * *}$ & 0.114 & $0.110^{* *}$ & -0.034 \\
\hline & (3.28) & (1.10) & (2.16) & $(-0.67)$ \\
\hline $\mathrm{N}$ & 8438 & 8438 & 8438 & 8438 \\
\hline $\begin{array}{l}\text { F-statistic in first stage } \\
\text { regression }\end{array}$ & 38.988 & 38.988 & 38.988 & 38.988 \\
\hline P-statistics in Hausman test & $\begin{array}{l}126.91 \\
(0.000)\end{array}$ & $\begin{array}{l}672.40 \\
(0.000)\end{array}$ & $\begin{array}{l}489.47 \\
(0.000)\end{array}$ & $\begin{array}{l}733.15 \\
(0.000)\end{array}$ \\
\hline
\end{tabular}

Note: Figures in brackets are the t statistics. ${ }^{* * *},{ }^{* *}$ and ${ }^{*}$ represent $1 \%, 5 \%$ and $10 \%$ significance level. Figures without brackets are marginal effects, namely $\mathrm{dF} / \mathrm{dx}$.

no savings because they have to use their private funds to meet the current demand of funds when they cannot borrow money from banks. Credit constraints can reduce the participation rate and allocation ratio of stock and risky financial assets. Those families who face credit constraints have lower risk tolerance, so they tend to avoid risky investment when selecting financial assets. In addition, this paper also analyzes the household selection in informal financial market. The results show that those families who face credit constraints tend to have more private borrowing and less private lending. Credit constraints mean that families cannot obtain loans from banks to meet their demand of funds, so those families who face credit constraints have to seek the private borrowing for help. Meanwhile, those families who face credit constraints are not willing to or unable to lend out money because they have to meet their owned demand of funds. In summary, credit constraints have a significant impact on household participation in formal and informal financial markets.

The research conclusions in this paper have strong policy implications for domestic financial practice. Firstly, 
Table 4. IV-Tobit regression.

\begin{tabular}{|c|c|c|c|c|}
\hline & (1) & (2) & (3) & (4) \\
\hline & Savings & Stock & Risky Assets & Private Lengding \\
\hline \multirow[t]{2}{*}{ Credit constraints } & $-0.1077^{* * *}$ & $-0.5016^{* * *}$ & $-0.1351^{* *}$ & $-0.1141^{* *}$ \\
\hline & $(-3.06)$ & $(-3.52)$ & $(-2.48)$ & $(-1.95)$ \\
\hline \multirow[t]{2}{*}{ Real estate } & -0.000 & 0.000 & $0.000^{* * *}$ & -0.000 \\
\hline & $(-0.53)$ & $(1.06)$ & (4.14) & $(-1.20)$ \\
\hline \multirow[t]{2}{*}{ Household income } & 0.000 & 0.000 & $0.000^{* *}$ & 0.000 \\
\hline & $(0.98)$ & $(0.36)$ & (3.26) & (1.49) \\
\hline \multirow[t]{2}{*}{ Risk-preference } & $-0.077^{* *}$ & $0.343^{* * *}$ & $0.147^{* * * *}$ & 0.028 \\
\hline & $(-2.51)$ & (3.76) & (3.55) & $(0.61)$ \\
\hline \multirow[t]{2}{*}{ Risk-aversion } & $-0.047^{* *}$ & -0.101 & $-0.138^{* * *}$ & $-0.112^{* * *}$ \\
\hline & $(-2.01)$ & $(-1.34)$ & $(-4.10)$ & $(-2.99)$ \\
\hline \multirow[t]{2}{*}{ Family size } & 0.015 & $0.114^{* * *}$ & $0.033^{* *}$ & $0.042^{* *}$ \\
\hline & (1.28) & (2.56) & (1.87) & $(2.21)$ \\
\hline \multirow[t]{2}{*}{ Male } & $0.047^{* *}$ & -0.060 & 0.027 & $0.112^{* * *}$ \\
\hline & (2.38) & $(-0.95)$ & $(0.95)$ & (3.45) \\
\hline \multirow[t]{2}{*}{ Age } & -0.001 & $-0.005^{*}$ & $-0.010^{* * *}$ & $-0.016^{* * * *}$ \\
\hline & $(-1.09)$ & $(-1.72)$ & $(-6.95)$ & $(-9.92)$ \\
\hline \multirow[t]{2}{*}{ Primary education } & $0.252^{* * * *}$ & 0.156 & $0.216^{* * *}$ & $0.206^{* *}$ \\
\hline & (6.10) & $(0.85)$ & (3.00) & $(2.54)$ \\
\hline \multirow[t]{2}{*}{ Secondary education } & $0.328^{* * * *}$ & $0.406^{*}$ & $0.311^{* * *}$ & 0.149 \\
\hline & (5.86) & (1.78) & (3.41) & $(1.46)$ \\
\hline \multirow[t]{2}{*}{ Higher education } & $0.363^{* * * *}$ & $0.478^{*}$ & $0.416^{* * * *}$ & 0.147 \\
\hline & (5.53) & $(1.84)$ & $(4.00)$ & (1.26) \\
\hline \multirow[t]{2}{*}{ Urban } & $0.086^{* * * *}$ & $0.170^{* *}$ & $0.101^{* * * *}$ & 0.005 \\
\hline & (3.49) & (1.97) & (2.72) & $(0.11)$ \\
\hline $\mathrm{N}$ & 8438 & 8438 & 8438 & 8438 \\
\hline $\begin{array}{l}\text { F-statistic in first } \\
\text { stage regression }\end{array}$ & 31.377 & 31.377 & 31.377 & 31.377 \\
\hline P-statistics in Hausman test & -7.71 & -13.36 & -5.69 & -4.25 \\
\hline
\end{tabular}

Note: Figures in brackets are the t statistics. ${ }^{* * *},{ }^{* *}$ and ${ }^{*}$ represent $1 \%, 5 \%$ and $10 \%$ significance level. Figures without brackets are marginal effects, namely $\mathrm{dF} / \mathrm{dx}$.

small loans for households should be supported and promoted. Approval conditions of household loans should be appropriately reduced. Bank loans are helpful for families to balance consumption and investment when they face cash flow problems in daily life. After solving financial problems, families have stronger motivation to invest financial assets. Meanwhile, reducing credit constraints of families can promote household participation in stock market. Secondly, actively developing informal financial market can be helpful for reducing credit constraints of families. Private borrowing can be the better option for those families who are not qualified to obtain bank loans. Based on private borrowing and lending, P2P internet financial platforms can meet household demand of micro-credit. Correctly standardizing private borrowing and lending can be beneficial to household financing and investing. Thirdly, education level and being urban both have a significant negative correlation with the participation rate and allocation ratio of stock and risky financial assets. Therefore, spreading and populariz- 
ing the knowledge of financial investment are helpful for increasing household participation rate of capital market. Reducing the urban-rural income gap and narrowing the wealth gap can encourage rural households to participate in stock market.

\section{References}

[1] Flavin, M. (1981) The Adjustment of Consumption to Changing Expectations about Future Income. Journal of Political Economy, 89, 974-1009. http://dx.doi.org/10.1086/261016

[2] Zeldes, S.P. (1989) Consumption and Liquidity Constraints: An Empirical Investigation. The Journal of Political Economy, 97, 305-346. http://dx.doi.org/10.1086/261605

[3] Haliassos, M. and Michaelides, A. (2003) Portfolio Choice and Liquidity Constraints. International Economic Review, 44, 143-177. http://dx.doi.org/10.1111/1468-2354.t01-1-00065

[4] Guiso, L., Haliassos, M. and Jappelli, T. (2000) Houshold Portfolios: An International Comparison. Department of Economics, University of CYPUS, 2-35.

[5] Yu, C.Q. (2001) An Empirical Analysis on the Relationship between China’s Financial Assets Structure and Economy Growth. Collected Essays on Finance and Economics, 9, 26-32.

[6] He, X.Q., Shi, W. and Zhou, K.G. (2009) Background Risk and Investors' Participation in Risky Financial Assets. Economic Research Journal, 12, 119-129.

[7] Yu, R. (2006) Research on the Household Financial Portfolio Choice in China. Jinan University, Guangzhou, 94-99.

[8] Wu, W.X., Yi, J.R. and Zheng, J.M. (2010) Household Portfolios in Chian: Empirical Analysis on the Effects of Life Cycle, Wealth and House. Economic Research Journal, 1, 72-82.

[9] Wang, C. and Tian, C.Z. (2012) Stock Market Participation, Participation Rate and Determinants. Economic Research Journal, 10, 97-106.

[10] Haliassos, M. and Bertaut, C.C. (1995) Why Do So Few Hold Stocks? The Economic Journal, 105, 1110-1129. http://dx.doi.org/10.2307/2235407

[11] Jappelli, T. and Cox, D. (1990) Credit Rationing and Private Transfers: Evidence from Survey Data. The Review of Economics and Statistics, 72, 445-454. http://dx.doi.org/10.2307/2109352

[12] Cheng, Y. and Luo, D. (2009) The Choice of Farmers' Entrepreneurship under Credit Constraints. Chinese Rural Economy, 11, 73-75.

[13] He, A.H. and Kong, X.Z. (2014) Research on the Relationship between Farmers Land Lease and Agricultural Investment Ratio. Chinese Rural Economy, 1, 13-15.

[14] Lian, Y.J., Li, W.S. and Huang, B.H. (2014) The Impact of Children Migration on the Health and Life Satisfaction of Parents Left behind. China Economic Quarterly, 14, 185-201.

[15] Lian, Y.J., Yu, W.D. and Ye, R.C. (2014) The Efficiency of Hausman Test Statistics: A Monte-Carlo Investigation. Journal of Applied Statistics and Management, 33, 830-840. 